\title{
EDITORIAL
}

Versão original

DOI: http://dx.doi.org/10.1590/So034-759020200401

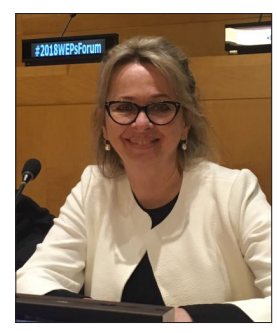

MARIA JOSÉ TONELLI Editora-chefe

\section{O FUTURO DAS REVISTAS CIENTÍFICAS}

A SciELO Brasil publicou uma atualização de seu documento "Critérios, política e procedimentos para a admissão e a permanência de periódicos na Coleção SciELO Brasil”, válida a partir de maio de 2020. Os critérios divulgados estão apoiados na proposta de Ciência Aberta, que inclui: i) acesso aberto, ii) dados abertos e iii) pareceres abertos. Ainda que não universalmente aceito, uma vez que interesses comerciais estão envolvidos nessa indústria, o primeiro indicador já é praticado pelos periódicos no Brasil. Cabe discutir os demais tópicos, que trazem algumas polêmicas.

Participei recentemente de um encontro de editores científicos, organizado pelo professor Fabio Frezatti, editor-chefe da Revista Contabilidade \& Finanças, com o professor Abel L. Packer, diretor do Programa SciELO/FAPESP. Aproveito para agradecer publicamente o encontro. O debate foi esclarecedor acerca de profundas mudanças que as revistas científicas deverão implementar nos próximos anos. Com o risco de cometer impropriedades, apresento aqui uma síntese pessoal dessa conversa, para continuar a reflexão sobre essas novas políticas de comunicação do conhecimento, junto com pesquisadoras e pesquisadores, editoras e editores científicos e pareceristas da comunidade acadêmica em Administração.

Essas transformações podem ter, daqui a alguns anos, um impacto na organização e comunicação de pesquisas científicas, bem como na própria gestão dos periódicos. Com o avanço das novas tecnologias, a gestão tradicional dos periódicos, que inclui periodicidade regular, volumes e todo o processo de produção das revistas, que está organizado para atender a esse modelo, pode ser completamente revista, com publicações contínuas, em plataformas que podem ser infinitamente renovadas em tempo (quase) real. As revistas desaparecem, mas a comunicação da produção científica fica mais ágil. Além dos dados, outras etapas do processo de produção da comunicação científica poderão estar abertas: a publicação dos pareceres e a conversação direta de editores científicos com os autores.

Quem são os responsáveis por essa transformação? Os periódicos têm papel protagonista nesse processo, mas é necessário contar com a adesão e participação das pesquisadoras e pesquisadores, de editoras e editores e pareceristas. Não é necessária uma mudança radical. Nessa nova trajetória, o posicionamento pode ser flexível e os avanços modulares em conjunto com a comunidade de pesquisa. 
A RAE segue as diretrizes da SciELO e busca os caminhos para acompanhar essas mudanças na comunicação científica. A seguir, selecionamos alguns links úteis para aprofundar esse debate.

\section{Sobre Ciência Aberta:}

\section{Ciência Aberta e o novo modus operandi de comunicar pesquisa - Parte I}

https://blog.scielo.org/blog/2019/08/01/ciencia-aberta-e-o-novo-modus-operandi-de-comunicar-pesquisaparte-i/\#.XuO2iVRKi5s

\section{Ciência Aberta e o novo modus operandi de comunicar pesquisa - Parte II}

https://blog.scielo.org/blog/2019/08/01/ciencia-aberta-e-o-novo-modus-operandi-de-comunicar-pesquisaparte-ii/

\section{Sobre avaliação aberta}

https://blog.scielo.org/blog/2018/02/28/sobre-as-vinte-e-duas-definicoes-de-revisao-por-pares-aberta-emais/\#.XuOoz1RKi5s

https://blog.scielo.org/blog/2019/04/30/potenciais-vantagens-e-desvantagens-na-publicacao-depareceres/\#.XuO2pFRKi5sE

https://blog.scielo.org/blog/2019/03/27/avaliacao-por-pares-aberta-a-publicacao-dos-pareceres-influenciao-comportamento-dos-pareceristas/\#.XuO2qFRKi5s

Desejamos a todas e todos uma boa leitura!

Maria José Tonelli' ${ }^{1}$ | ORCID: 0000-0002-6585-1493

${ }^{1}$ Fundação Getulio Vargas, Escola de Administração de Empresas de São Paulo, São Paulo, SP, Brasil 